\title{
An empirical analysis of imprisoning drug offenders
}

\author{
Ilyana Kuziemko ${ }^{a}$, Steven D. Levitt ${ }^{\text {b,* }}$ \\ ${ }^{a}$ Department of Economics, Littauer Hall, Harvard University, Cambridge, MA 02138, USA \\ ${ }^{\mathrm{b}}$ University of Chicago and American Bar Foundation, 1126 E. 59th Street, Chicago, IL 60637, USA
}

Received 15 August 2001; received in revised form 27 January 2003; accepted 28 January 2003

\begin{abstract}
The number of prisoners incarcerated on drug-related offenses rose 15-fold between 1980 and 2000. This paper provides the first systematic empirical analysis of the implications of that dramatic shift in public policy. We estimate that cocaine prices are $5-15 \%$ higher today as a consequence of increases in drug punishment since 1985, presumably leading to reduced drug consumption. Incarcerating drug offenders is found to be almost as effective in reducing violent and property crime as locking up other types of offenders. Thus, although we demonstrate that the increase in drug prisoners led to reductions in expected time served for other crimes (especially for less serious offenses), the overall impact of increased drug incarceration has likely been a small $(1-3 \%)$ reduction in violent and property crime. Back-of-the envelope estimates suggest that it is unlikely that the dramatic increase in drug imprisonment was cost-effective.
\end{abstract}

(C) 2003 Elsevier B.V. All rights reserved.

Keywords: Incarceration; Drug-related offenses; Public policy; Drug consumption

\section{Introduction}

Public policy towards drug offenders has undergone a dramatic transformation in the United States over the last two decades. In 1980, approximately 24000 inmates in US prisons (state and federal combined) had drug crimes as their most serious offense. Twenty years later, that number is estimated to be near 400 000. Drug offenders now make up over $30 \%$ of all inmates in state and federal prisons, compared to less than $8 \%$ in 1980 . The enormous increase in incarcerated drug offenders has come at a time when US drug use, as

\footnotetext{
* Corresponding author.

E-mail addresses: kuziemko@nber.org (I. Kuziemko), slevitt@midway.uchicago.edu (S.D. Levitt).
} 
measured by self-report surveys is relatively flat (Basov et al., 2001) or even falling (Reinarman and Levine, 1997).

There is a large body of literature analyzing the causes and consequences of the increased criminal justice response to the drug trade (for example, Boaz, 1990; Duke and Gross, 1993; Benson and Rasmussen, 1994; Donziger, 1996; Nadelman, 1997; MacCoun and Reuter, 2001). Prohibition of drugs and the accompanying punishments are motivated by a commonly held (but not universally accepted) belief that drug use imposes negative externalities on society. Critics of the current policies, however, argue that the costs associated with prohibition far outweigh any consumption externalities. For instance, if the demand for drugs is inelastic, greater punishment of drug sellers is likely to increase the rents associated with drug distribution, perhaps increasing the level of violence associated with establishing and maintaining property rights (Becker et al., 2001). Moreover, if the marginal imprisoned drug criminal commits fewer crimes than the marginal imprisoned violent or property criminal, allocating scarce prison space to drug offenders may be inefficient. In the extreme case of a perfectly inelastic supply of prison cells, increased drug punishments will crowd out sentences of other offenders one for one, potentially leading to higher crime rates through this channel as well. Even former proponents of the approach, including ex-Drug Czar William McCaffrey and the Republican Governor of New York, George Pataki, have recently expressed reservations about the continued emphasis on incarceration in combating the drug problem (Alter, 2001; Perez-Pena, 2001).

In spite of the great uncertainty about the consequences of the war on drugs, however, there has been remarkably little rigorous empirical analysis of the impact of these policies. ${ }^{1}$ Benson and Rasmussen (1991), using a cross-section of Florida counties, find that counties with high rates of drug arrests have lower clearance rates for property crime. One interpretation of this result is that diversion of police resources to drug offenses reduces the ability to fight other crimes. Miron (1999) demonstrates that homicide rates are positively related to drug and alcohol prohibition policies. With respect to the impact of criminal justice sanctions on drug consumption, both DeSimone (1998) and Chaloupka et al. (1999) show a negative, but relatively weak, relationship between the severity of statutory sanctions for drug use and higher drug consumption. Farrelly et al. (2000) identifies a negative relationship between the certainty and severity of marijuana punishment and marijuana usage. We are unaware of any empirical studies addressing a number of other fundamental issues in the evaluation of criminal justice policies towards drug offenders: the extent to which the imprisonment of drug prisoners has crowded-out other types of offenders from prisons, the relative crime reduction achieved from incarcerating drug offenders vis-a-vis other criminals, or even the relationship between drug punishment and drug prices.

In this paper, we provide a first attempt at a systematic analysis of those questions. We begin with an examination of the impact of drug punishment on cocaine prices. We construct estimates of cocaine prices by city and year using the System to Retrieve Information from Drug Evidence (STRIDE). We find some evidence that harsher punishments for drug offenders are associated with higher drug prices. The combined increase in

1 For a thoughtful and careful survey of the existing evidence on drug enforcement, see MacCoun and Reuter (2001). 
the certainty and severity of drug punishment between 1985 and 1996 is estimated to have raised the street price of cocaine $12-14 \%$. These findings suggest that the current drug policy imposes a non-trivial cost on drug suppliers. Higher prices should be associated with lower rates of consumption, although there is enormous uncertainty about the price elasticity of demand for illegal hard drugs, with estimates ranging from -0.2 to -1.8 (Van Ours, 1995; Saffer and Chaloupka, 1995; Grossman and Chaloupka, 1998; Chaloupka et al., 1999; Liu, 1999).

The remainder of the paper focuses on how increased punishment for drug offenses affects other crime rates. We first show that, on the margin, locking up a drug offender reduces violent and property crime almost as much as incarcerating other types of criminals (although our estimates are not very precise). ${ }^{2}$ If the rise in drug imprisonment represented a true increase in the prison population, then our results imply that violent and property crime might be as much as $2-5 \%$ lower today (relative to a counterfactual maintaining 1980 drug incarceration rates) as a consequence of tougher drug punishments. That estimate is likely to overstate the true impact on crime, however, because the supply of prison cells is not perfectly elastic. Increased drug punishment is likely to crowd out punishment for other offenses. Indeed, we empirically demonstrate that there are substantial (but far from one-for-one) crowdout effects. Nonetheless, the overall conclusion of our research is that, on the margin, increased drug punishments result in slightly lower rates of property and violent crime.

In summary, our findings concerning the impact of drug punishment are not nearly as pessimistic as critics of drug policy might have predicted: prices appear to be higher and crime lower as a consequence of the increased incarceration. It is important to note, however, that there are many important caveats regarding our results. First, the relevance to public policy is limited by the fact that we have no power to test the efficacy of the current drug regime versus alternative approaches such as legalization or increased availability of drug treatment facilities. Even though our results suggest that the criminal justice approach is at least somewhat successful, it is possible that other approaches would have been more cost-effective in achieving the same goals. Second, the data we use, although the best available, are nonetheless of questionable quality. ${ }^{3}$ Third, while we consider a range of outcome variables, there are other consequences of drug policy that we do not examine, e.g., the effect of anti-drug efforts on municipal or state budgets. Fourth, much of the analysis that we conduct is correlational in nature, despite the fact that earlier research highlights the importance of endogeneity in the criminal justice system (Fisher and Nagin, 1978; Levitt, 1996, 1998). In most of our applications, however, it is possible to sign the likely biases in our estimates that result from relying on correlations.

The remainder of the paper is structured as follows. Section 2 briefly overviews the economics of drug prohibition. Section 3 assesses the relationship between drug punishment and drug prices. Section 4 analyzes the link between the scale of imprisonment,

\footnotetext{
2 The effectiveness of locking up drug offenders in reducing crime may be a consequence either of drug offenders committing other crimes at rates comparable to those of criminals arrested for non-drug crimes, or an indirect benefit coming from reductions in the drug trade. We are not able to empirically distinguish between these two channels.

3 For a highly critical discussion of the state of available data on drug consumption and prices see National Research Council (2001).
} 


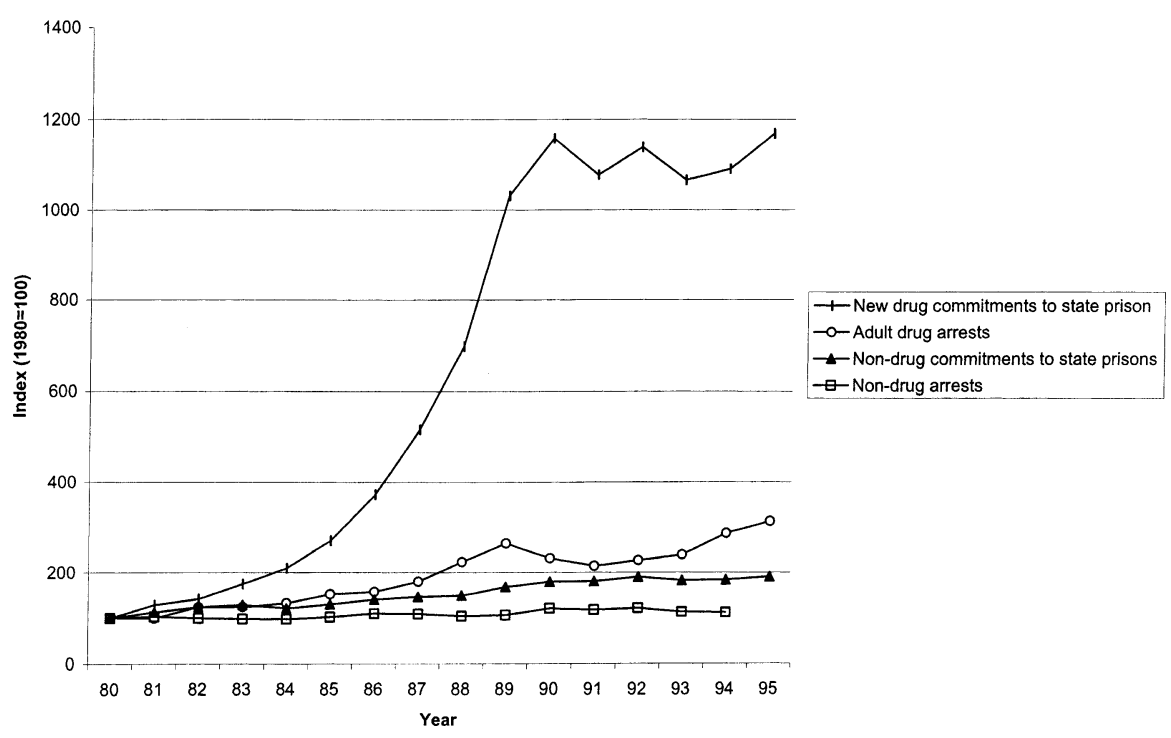

Fig. 1. Arrests and state prison commitments by crime type.

expected punishments for drug and non-drug offenders, and property and violent crime. Section 5 presents estimates of the crowd-out effect of drug prisoners on inmates convicted for other crimes. Section 6 concludes.

\section{The economics of fighting drugs and american drug public policy}

The dominant economic feature differentiating the market for illicit drugs from other products is the strict prohibition on their distribution and use, enforced by criminal punishments. Fig. 1 demonstrates the profound shift in United States policy towards drugs in the last two decades. The figure presents national time series data for the number of adult drug-related arrests and new commitments of drug offenders to state prisons. For purposes of comparison, arrests for Index (violent and property) crimes and new commitments to state prisons for these crimes are also shown, ${ }^{4}$ as is the total number of prisoners whose most serious offenses is drug related. In all cases, the time series are indexed with the 1980 value normalized to 100 in order to facilitate comparisons. The most striking result in the figure is that new drug commitments to state prisons increased more than 10 -fold in less than a decade (to a rate of approximately 100000 per year). The increase in drug-related prison commitments far outpaced the increases in drug arrests, although that number itself more than tripled during the time period to over 1.5 million annually. While not shown in the figure, the trend in the

\footnotetext{
4 We present these particular data series because it is possible to gather consistent data over the entire period. Including federal prisons does not alter the picture, but data are not available in all years.
} 
number of drug prisoners (i.e., the stock of those incarcerated, as opposed to the flow) is virtually identical to that of new drug commitments, implying that none of the increase in the number of drug prisoners is a consequence of longer prison terms conditional on being sentenced to prison. ${ }^{5}$ Non-drug arrests have been essentially flat over this time period, whereas non-drug commitments to prison approximately doubled. Thus, while less pronounced than in the drug case, the trend toward greater use of prisons for punishing other crimes is also apparent.

The prohibition of illegal drugs stands in stark contrast to the Pigouvian tax approach used to internalize the externalities associated with similar products such as tobacco and alcohol. Benson and Rasmussen (1994), Miron and Zweibel (1995), and Becker et al. (2001) analyze the economics of prohibited goods. At a fixed price, the supply of a prohibited good is likely to be lower than if that good were freely traded. Avoiding detection introduces inefficiency into the production and distribution of goods. For instance, under the current regime, manufacturing of cocaine is done at an inefficiently small scale in operations hidden in remote areas of South America; the product is then smuggled into the United States at high cost; and the final steps in producing and packaging crack cocaine are carried out in the retail distributor's kitchen. ${ }^{6}$ Furthermore, the street price of the good must be elevated to compensate distributors for both the risk of punishment and the non-trivial fraction of illegal goods that are confiscated by authorities. $^{7}$ The Drug Enforcement Agency (DEA, 1996) estimated global cocaine production in 1996 to be 700 metric tons. The amount of cocaine seized worldwide in 1996 exceeded 200 metric tons (or about $30 \%$ of the total produced), with US Federal law enforcement agencies accounting for a majority of the seizures. On the demand side, at any given price, the quantity consumed of an illegal drug is likely to be lower than if that drug were legal, due both to stigma effects and the risk of punishment a user faces. ${ }^{8}$ Thus, the basic prediction of the standard economic model is that when a good is prohibited, the quantity consumed will be unambiguously lower, but the impact on price is indeterminate. Note, however, that even in the presence of a negative consumption externality (which makes the decline in quantity desirable), the prohibition need not be welfare improving relative to the free market equilibrium. Enforcement costs must also be considered, and possibly (depending on one's view) the foregone utility from consumption. In addition, if demand is inelastic, the prohibition may raise rents to producers, leading to increased diversion of otherwise productive resources to the production of drugs (Becker et al., 2001).

\footnotetext{
5 In contrast, Basov et al. (2001) do find a trend toward longer sentences in federal prisons.

6 Although Miron (2000) argues that the regulatory compliance costs for legally produced goods is substantial-perhaps even as great as these detection avoidance costs for prohibited goods.

7 It is often argued by critics of government drug policy that the supply of labor to the drug market is quite elastic (e.g., Moore, 1990; Benson and Rasmussen, 1994), i.e., when one drug dealer is incarcerated, another person simply takes his place with little disruption to the drug-selling operation. Even if this is true, however, one would expect increasing drug punishments to induce an inward shift of the supply curve since drug sellers must be compensated for the increased risk of punishment. Levitt and Venkatesh (2000) present empirical evidence that wages of street-level sellers rise when the risks associated with drug dealing rise.

8 Offsetting these factors would be any increased desirability of consuming the illegal good due to its 'forbidden fruit' nature.
} 


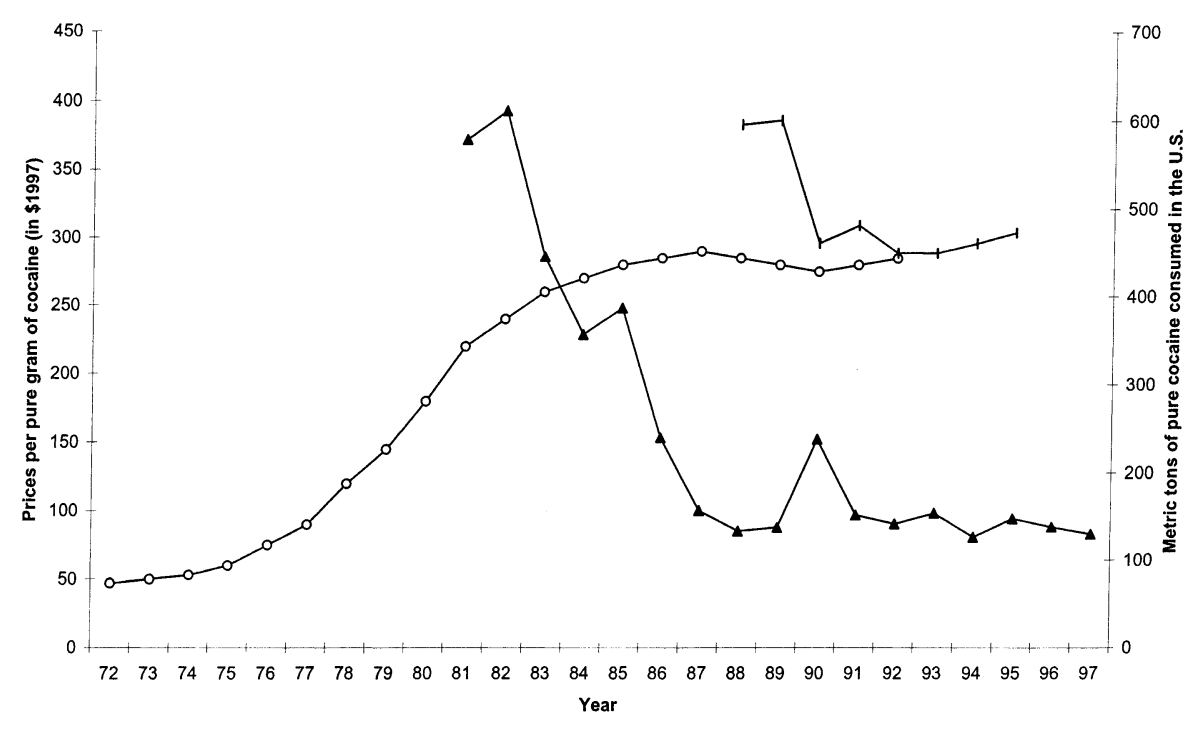

-O-RAND consumption - - ABT consumption $\rightarrow$ Price of cocaine

Fig. 2. Cocaine price and consumption estimates.

As demonstrated in Fig. 1 above, imprisonment for drug-related offenses in the United States over the last two decades increased dramatically. Given that incarceration is overwhelmingly directed at drug traffickers as opposed to drug users, ${ }^{9}$ one would expect to have seen rising drug prices and falling drug quantities as punishment rose. In practice, however, this was not the case. Fig. 2 presents yearly estimates of cocaine prices and quantities in the United States. Prices in the figure are estimates from Rhodes and Kling (1997) which uses information from the DEA's STRIDE database of undercover drug purchases. We report two different sets of estimates on aggregate US cocaine consumption over time, one from RAND researchers (Everingham et al., 1995) and the other from Rhodes et al. (1998). ${ }^{10}$ Cocaine prices fell sharply through most of the 1980s, and have remained essentially flat since that time. Consumption of cocaine rose sharply as the price fell in the 1980s. Depending on which estimate of consumption one relies upon, cocaine use either stayed level since the late 1980s, or fell sharply in the late 1980s before leveling off. The pattern of falling prices and rising consumption in the $1980 \mathrm{~s}$ is precisely the opposite of what would be expected based on the incarceration patterns. Rather than an

9 According to Bureau of Justice Statistics (1995), although almost three-quarters of drug-related arrests are for possession rather than trafficking, two-thirds of drug-related convictions are for trafficking. A higher fraction of those charged with trafficking are sentenced to jail or prison, and mean maximum sentences of traffickers are three times longer. Thus, as of 1993 , our calculations suggest that $86 \%$ of all drug-related time incarcerated was on trafficking charges. To the extent that some of those convicted of possession were in fact drug dealers caught with only small amounts of drugs, the true fraction is likely to be even higher.

10 Cocaine consumption estimates are based on estimated prevalence of use from household survey data, combined with estimates of expenditures per user and the price of cocaine. See the original sources for greater detail on the methodologies. For our purposes, it is important to note that the estimated quantities are based in part on estimated cocaine prices, potentially inducing a mechanical negative relationship between price and quantity. 
inward shift in supply, these data appear consistent with a dramatic outward shift in supply, perhaps do to increased efficiency and sophistication on the part of drug cartels, smugglers, and retailers. Combining the information in Figs. 1 and 2, it is easy to understand the broad criticism that has been leveled against the 'War on Drugs,' although it is unclear whether prices may have fallen even further and consumption increased even more had increased punishment not been put into place.

Further reinforcing criticism of increasing punishments for drug offenders is the fact that the empirical relationship between prohibition and elevated violence is well documented (Miron, 1999). Peak murder rates in the United States in the twentieth century correspond to the early 1930s, when Prohibition was in place, and the early 1990s when the War on Drugs was in full force. The primary reason for the link between violence and prohibition appears to be the absence of legally enforceable property rights in illicit markets. While it seems clear that a policy of prohibition fosters violence, it is less obvious whether crime will rise or fall when punishment increases for an already prohibited good. In the short run, greater enforcement can lead to rising violence by disrupting the existing allocation of property rights. If a drug lord who controls an area is removed, competition (often in the form of violence) among those attempting to establish dominance is likely to ensue. On the other hand, the willingness to engage in violence should be linked to the possible profits associated with illegal drug distribution. To the extent that increased drug enforcement reduces the demand for illicit drugs, profits will fall, and in the long-run, violence should also decrease.

The impact of increased punishment on the number of crimes committed by drug users to raise money to support their drug use is also indeterminate. If the demand for drugs was perfectly inelastic, than an increase in the price of drugs would likely lead to more crime among addicts attempting to support their habit. If, however, drug consumption falls in response to increased enforcement, this need not be the case.

An alternative channel through which drug enforcement can affect violence is by crowding-out criminal justice resources for fighting other types of crime. At least in the short run, such an argument appears plausible. Virtually every state prison system in the country is at or near capacity and has been for at least a decade (Selke, 1993). Increasing capacity through the construction of new prisons takes many years to complete. There are, however, a number of other margins along which a prison system can accommodate increases in inmates in the near term, including overcrowding existing prison facilities, housing prisoners in jails (which are typically reserved for individuals awaiting trial or those with sentences of less than a year), using private prison providers, or contracting with other states that have excess prison capacity. With the exception of prison overcrowding, which is endemic, use of the other strategies has been relatively limited in scope. Diversion of police, prosecutor, and court resources away from other crimes towards drug offenses are also possible.

\section{Data sources}

We utilize a number of different data sources in this paper, which are described in the data appendix. Summary statistics are provided in Table 1. In addition to standard data 
Table 1

Summary statistics

\begin{tabular}{|c|c|c|c|c|}
\hline \multirow[t]{2}{*}{ Variable } & \multirow[t]{2}{*}{ Mean } & \multicolumn{3}{|c|}{ Standard deviation } \\
\hline & & Overall & $\begin{array}{l}\text { Removing } \\
\text { state-fixed } \\
\text { effects }\end{array}$ & $\begin{array}{l}\text { Removing } \\
\text { state- and } \\
\text { year-fixed } \\
\text { effects }\end{array}$ \\
\hline \multicolumn{5}{|l|}{ Percent of new state prison admissions for: } \\
\hline drug offenses & 0.220 & 0.104 & 0.062 & 0.038 \\
\hline violent offenses & 0.225 & 0.180 & 0.160 & 0.159 \\
\hline property offenses & 0.229 & 0.143 & 0.125 & 0.121 \\
\hline other offenses & 0.341 & 0.196 & 0.166 & 0.163 \\
\hline \multicolumn{5}{|l|}{ Median $\%$ of sentence served } \\
\hline robbery & 0.353 & 0.140 & 0.072 & 0.070 \\
\hline auto theft & 0.462 & 0.197 & 0.104 & 0.100 \\
\hline rape & 0.422 & 0.151 & 0.096 & 0.085 \\
\hline burglary & 0.335 & 0.141 & 0.069 & 0.068 \\
\hline aggravated assault & 0.372 & 0.125 & 0.069 & 0.067 \\
\hline Fraud & 0.333 & 0.150 & 0.090 & 0.070 \\
\hline Larceny & 0.351 & 0.149 & 0.090 & 0.089 \\
\hline Murder & 0.324 & 0.126 & 0.093 & 0.088 \\
\hline drug offenses & 0.307 & 0.141 & 0.068 & 0.066 \\
\hline Unemployment rate & 0.060 & 0.020 & 0.013 & 0.009 \\
\hline Black share of population & 0.125 & 0.122 & 0.004 & 0.003 \\
\hline Per capita income (in 1998 dollars) & 22,183 & 3683 & 1362 & 519 \\
\hline Per capita malt liquor purchases & 23.39 & 4.39 & 1.17 & 1.08 \\
\hline Cocaine prices (in 1998 dollars per pure gram) & 105.7 & 59.4 & 50.0 & 31.1 \\
\hline Per capita drug arrests & 0.0039 & 0.0028 & 0.0009 & 0.0007 \\
\hline Per capita violent arrests & 0.0022 & 0.0014 & 0.0004 & 0.0004 \\
\hline Per capita property arrests & 0.0077 & 0.0025 & 0.0009 & 0.0008 \\
\hline Commitment rate for drug offenders & 0.063 & 0.084 & 0.076 & 0.073 \\
\hline Commitment rate for violent offenders & 0.119 & 0.130 & 0.114 & 0.113 \\
\hline Commitment rate for property offenders & 0.033 & 0.038 & 0.0330 & 0.0323 \\
\hline Per capita violent crime & 0.0061 & 0.0039 & 0.0011 & 0.0009 \\
\hline Per capita property crime & 0.0464 & 0.0123 & 0.0038 & 0.0034 \\
\hline Per capita prison population & 0.0028 & 0.0020 & 0.0009 & 0.0006 \\
\hline
\end{tabular}

Notes: All variables correspond to state-year pairs, except cocaine prices which vary by city and year. Data cover the period 1983-1996. Data on prison admissions and time served are computed based on National Crime Reporting Program (NCRP) data. Other criminal justice variables are from Federal Bureau of Investigation Uniform Crime Reports. The remaining variables are from a variety of readily available sources and were collected by Donohue and Levitt (2001). Commitment rates are new prison commitments per arrest. Columns 3 and 4 report the standard deviation in variables after state-fixed effects and state-fixed effects and year dummies are included.

sources (e.g., the FBI's Uniform Crime Reports of the number of crimes and arrests, as well government generated measures of state income, unemployment, and racial composition), we rely heavily on two less familiar data sources. The first of these is the National Crime Reporting Program (NCRP) administered by Bureau of Justice Statistics. NCRP provides two separate individual-level data files for participating states: one data set contains all prison commitments, the other has all prison releases. Data collection began in 1983 with 29 states, and has continued annually, with the number of participating states 
rising to 37 in 1996, the most recent year available. A number of states report incomplete or clearly flawed data, especially in the earlier years; we are thus forced to eliminate 152 state-year pairs of data from our analysis, or $29 \%$ of state-year observations for the time period 1983-1996. Among the variables included for those being committed to prison are whether they are being newly committed (as opposed to being re-committed due to a parole revocation), the most serious offense among the current set of charges, and the maximum time to be served. ${ }^{11}$ The data set on prison releases includes those variables, as well as actual time served. The top panel of Table 1 presents summary statistics for the NCRP data used in this analysis. Drug offenders represent over $20 \%$ of all new commitments. The median percent of time served ranges from 30 to $46 \%$ of the maximum sentence handed down. Contrary to public perception regarding mandatory minimum sentencing of drug offenders, the fraction of time served by such criminals in state prisons is actually the lowest of all crime categories included.

In our empirical analysis, we include state-fixed effects to capture any omitted state characteristics that remain constant over time, as well as year dummies to absorb annual nationwide fluctuations. Column 3 of Table 1 presents standard deviations of the variables after these state and year indicators are removed. For the NCRP data, between 30 and 60\% of the overall variation remains. For variables like the Black share of population in a state or state per capita income, the fraction of variation that remains is much smaller.

A second data source is the Drug Enforcement Agency's STRIDE data set, which has been collected since 1981. Included in the data set is information on the price paid, quantity purchased, location of the sale, and purity of the drug for undercover purchases by DEA agents. In a typical year, more than 2000 cocaine/crack cocaine purchases are included in the data set. The STRIDE data have a number of important weaknesses. First, the drug purchases included in the data are by no means a random sample of all drug transactions. Second, for many cities and states, the number of observations per year is relatively small. ${ }^{12}$ Finally, the data appear to be quite noisy, with large variation in prices and purity within a given city and year. While some of this variation is likely to reflect real heterogeneity within markets, there can be little doubt upon careful examination of the data that coding errors are partly responsible. Nonetheless, it is important to bear in mind that since drug prices are used exclusively as a left-hand side variable in the analysis, to the extent that the errors in these prices are uncorrelated with our right-hand-side variables, the only impact will be to reduce the precision of our estimates.

\section{The impact of drug incarceration on drug prices}

One of the primary goals of the increased punishment of drug offenders is to decrease the consumption of illegal drugs. Roughly $85 \%$ of drug-related incarceration is for the

\footnotetext{
11 The data also include limited individual-level characteristics, such as age, gender, and race of the offender, although we do not make use of this information in the current paper since we focus only on aggregated data. No information on prior criminal activity is available in the data.

${ }^{12}$ Although for a large city such as Chicago, more than 150 individual cocaine/crack cocaine buys of 5 ounces or less are reported.
} 
distribution of drugs, as opposed to possession or consumption. Thus, one would expect that the primary impact of the dramatic increase in drug imprisonment would be to shift the supply curve inward, leading to an increased street-price of drugs and decreased usage. Although the aggregate time-series evidence presented in Fig. 2 is not consistent with that prediction, it is possible that the increase in drug punishment has indeed had the predicted effect, but that other factors such as technological advances in drug production and distribution have offset the incarceration-driven supply shift. If that is the case, then absent the increase in punishment for drugs, the street-price of drugs might be much lower and quantity of drugs consumed much higher than currently observed.

We employ two different cocaine price indexes derived from the STRIDE data as proxies for the street-level price of drugs. The first price index was developed by Rhodes and Kling (1997). They use STRIDE data to construct an annual, city-level time series on cocaine prices for 31 large US cities. In addition, we have created our own state-level cocaine price series by estimating regressions of the form:

$$
\text { Price }_{i s t}=X_{i s t}^{\prime} \Gamma+\theta_{s t}+\epsilon_{i s t}
$$

where $i, s$, and $t$ correspond to individual drug buys, state and year, respectively. The unit of observation is an individual drug buy recorded in STRIDE. Price is the price in nominal dollars paid per pure gram of cocaine. Because of concerns about data errors, we exclude from our sample the $5 \%$ of observations in each year with the lowest and highest recorded prices per pure gram. To be included in the estimation, there must be at least 50 price observations for a particular state and year. The vector $X$ includes the weight of drugs purchased, the purity of the purchased product, and the weight of pure cocaine in the purchase, as well as all those quantities squared and cubed. In addition, we include an exhaustive set of state-year interactions. The estimated parameters on the state-year interactions serve as an alternative to the Rhodes and Kling price series. We do not report the results of this estimation in tabular form because of the sheer volume of the parameters of primary interest (over 200 state-year interactions are estimated). The other control variables in the regressions appear sensibly estimated, e.g., larger purchases are associated with lower prices per pure gram of cocaine, indicating volume discounts. In addition, the price series generated by the state-year interactions behave in a reasonable fashion. Although there is variability in both the price levels and patterns over time (as would be expected), almost all states show sharp price declines in the 1980s and relatively stable prices in the 1990s. ${ }^{13}$ The correlation between our price index and that of Rhodes and Kling is 0.75 .

Although we report results for both of these price indexes, for our purposes, the one we have construct has a number of advantages over the Rhodes and Kling index. First, all of the variation in our criminal justice variables is at the state level, so it is convenient to have our price index at that same level of aggregation. Second, by using states instead of cities, there are a greater number of areas with sufficient data to support estimation. Finally, because we estimated our price index, we have the flexibility to explore its sensitivity to alternative assumptions and data choices. We find that our results are very similar whether

\footnotetext{
13 Full results for this specification and all others not reported in their entirety in the paper are available from the authors on request.
} 
we trim the top and bottom $5 \%$ of the data, or the top and bottom $10 \%$ of the data (correlations in these two state-level price indexes of 0.96). ${ }^{14}$

Using either our own estimated state-year price measures, or those of Rhodes and Kling, we estimate a reduced-form relationship between drug prices and criminal justice variables as follows:

$$
P_{s t}=\Sigma_{o}\left(\beta_{o} \text { Certainty }_{\text {sto }}+\gamma_{o} \text { Severity }_{\text {sto }}\right)+X_{s t}^{\prime} \Gamma+\lambda_{s}+\theta_{t}+\epsilon_{s t}
$$

where $s$ indexes cities, $t$ corresponds to years, and $o$ represents offense categories (i.e., drug, violent, or property). The dependent variable is the estimated city-level cocaine prices. Certainty is the number of arrests per capita for the relevant offense category. Severity is the fraction of arrests for a given offense category which result in the criminal being sentenced to prison. Other covariates (represented by the vector $X$ in the equation) in the specifications are the unemployment rate, per capita income, the Black share of the population, per capita malt liquor consumption, and the 'effective' abortion rate (Donohue and Levitt, 2001). ${ }^{15}$ All of these covariates are available annually at the state level. Statefixed effects and year dummies are included in all regressions. ${ }^{16}$

The two criminal justice measures in the regression are clearly imperfect. The arrest rate per capita is affected not only by the certainty of punishment, but also by the level of criminal activity in a city. ${ }^{17}$ For a fixed likelihood of apprehension, the greater the underlying amount of crime, the higher is the arrest rate per capita. Furthermore, drug prices are likely to be correlated with the scale of criminal activity, although the direction of the correlation will vary depending on whether fluctuations in prices are driven by shocks to supply or demand. As a consequence, the direction and magnitude of the empirical bias associated with using the arrest rate per capita as a measure are difficult to judge a priori. ${ }^{18}$ If changes in drug prices within a city over time are primarily driven by city-level demand shifts (which would not be absorbed in either city-fixed effects or national-level year dummies) and the probability of punishment remains constant over time, then for reasonable parameter values, one would expect a positive relationship between the arrest rate variable and drug prices that is not causally related to drug punishment. On the other hand, if cities systematically increase arrest

14 In stark contrast, if we use all the observations in the data, including the extreme outliers, the results are nonsensical, which gives us pause about using a price index we have not ourselves been able to test for sensitivity.

15 The 'effective' abortion rate is the weighted average abortion rate for individuals born in a state, with weights determined by the national average fraction of arrests for violent crime by age group.

${ }_{16}$ We have also experimented with including state-level trends in the specification. In these regressions, as well as the other analysis performed in the paper, the resulting standard errors become prohibitively large, precluding meaningful interpretation. When we use the Rhodes and Kling price series, we actually run the regression at the unit of city-year observations because that is the level of aggregation of the left-hand-side variable. The right-hand-side variables in the regression vary only at the state level, however, so the reported standard errors have been corrected to take into account the state-level clustering of the data.

17 For property crimes and violent crimes, we do have measures of the number of offenses so it would be possible to use arrests per crime rather than arrests per capita as measures of certainty of punishment. The coefficient on drug arrests per capita are not systematically changed when that alternative specification is utilized.

18 For a thorough and insightful treatment of this subtle issue, see Pacula et al. (2001). 
rates in response to falling drug prices, the $\beta_{d}$ coefficient could yield a spurious negative relationship between drug prices and arrests, even if the true relationship is positive.

The proxy for severity of punishment - the fraction of arrests that result in prison terms - would appear to be less sensitive to such biases than the arrests per capita variable. The primary weakness of our severity measure is that it focuses solely on whether an individual is sent to prison, ignoring the expected time served. We use this variable because of the absence of well-defined measures of expected time served. It is worth noting, however, that when we adjust this variable to incorporate expected time served using proxies we construct from NCRP data, the results obtained are similar.

The empirical results from the estimation of Eq. (2) are presented in Table 2. The dependent variable in columns $1-3$ is the state-level price index we constructed. In columns 4-6, the city-level index of Rhodes and Kling (1997) is used. Column 1 includes the proxy for certainty of punishment (as well as the other covariates included in the earlier tables), but not the proxy for severity. Column 2 does the reverse. Column 3 includes both measures together. Regardless of the specification or the price index used, the coefficient on per capita drug arrests (our proxy for certainty of punishment) is strongly positive and highly statistically significant. A one-standard deviation increase in the rate of drug arrests (implying an additional 280 drug arrests per 100000 residents annually) is associated with a $12-22 \%$ rise in the street-price of cocaine. The results for commitment rates per drug arrest (our proxy for severity), are decidedly mixed and never statistically significant. For the price proxy we created (columns 1-3), the sign is much more mixed, but not statistically significant. The point estimates imply that a one-standard deviation increase in this variable (making the probability of going to prison conditional on a drug arrest 8 percentage points higher), is associated with cocaine prices that are between $2 \%$ lower and $9 \%$ higher. Comparing our sample average values of drug arrest rates per capita in 1985 and 1996 (0.0046 versus 0.0060$)$, the increase in arrests would imply a cocaine price rise of roughly $6-11 \%$. A similar calculation for commitments to prison conditional on being arrested (which rose from 0.026 to 0.061 ) suggests an impact that ranges between a $1 \%$ reduction and a $4 \%$ increase in cocaine prices. The combined impact of changes in drug policy between 1985 and 1996 is thus estimated to have raised cocaine prices between 5 and $15 \%$.

The long-run price elasticity of demand for hard drugs is a parameter that is not known with any degree of confidence. Moore (1991) and Becker et al. (1992) report estimates (for heroin) of around -0.2 to -0.3 , but for opium and cocaine the estimates typically range between -1.0 and -1.8 (Van Ours, 1995; Saffer and Chaloupka, 1995; Grossman and Chaloupka, 1998; Liu, 1999). Using an elasticity of -1.0 as a baseline, we estimate that the increase in price associated with rising drug punishments between 1985 and 1996 lowered the quantity of cocaine consumed by $5-15 \% .{ }^{19}$ Using elasticities at the low end

\footnotetext{
19 This estimate is consistent with the findings of Farrelly et al. (2000), who estimate an elasticity of marijuana usage with respect to marijuana punishments equal to -0.3 .
} 
Table 2

The effect of drug admissions on median $\%$ of sentence served across offense categories

\begin{tabular}{|c|c|c|c|c|c|c|c|c|c|}
\hline \multirow[t]{2}{*}{ Variable } & \multicolumn{9}{|c|}{ Median percent of maximum sentence actually served by offense type } \\
\hline & Murder & Rape & Robbery & $\begin{array}{l}\text { Agg. } \\
\text { assault }\end{array}$ & Fraud & Burglary & Larceny & Auto & $\begin{array}{l}\text { Drug } \\
\text { offenses }\end{array}$ \\
\hline $\begin{array}{l}\text { Percent of new } \\
\text { prison admissions } \\
\text { for drug offenses }\end{array}$ & $\begin{array}{c}-0.226 \\
(0.143)\end{array}$ & $\begin{array}{c}0.018 \\
(0.131)\end{array}$ & $\begin{array}{c}-0.372 \\
(0.113)\end{array}$ & $\begin{array}{c}-0.353 \\
(0.111)\end{array}$ & $\begin{array}{c}-0.311 \\
(0.126)\end{array}$ & $\begin{array}{c}-0.657 \\
(0.117)\end{array}$ & $\begin{array}{c}-0.536 \\
(0.137)\end{array}$ & $\begin{array}{c}-1.026 \\
(0.201)\end{array}$ & $\begin{array}{c}-0.601 \\
(0.109)\end{array}$ \\
\hline Unemployment rate & $\begin{array}{c}-0.38 \\
(0.69)\end{array}$ & $\begin{array}{r}-0.44 \\
(0.64)\end{array}$ & $\begin{array}{l}-1.08 \\
(0.56)\end{array}$ & $\begin{array}{c}-1.37 \\
(0.54)\end{array}$ & $\begin{array}{c}-0.44 \\
(0.61)\end{array}$ & $\begin{array}{c}-1.01 \\
(0.58)\end{array}$ & $\begin{array}{c}-0.23 \\
(0.66)\end{array}$ & $\begin{array}{l}-1.73 \\
(1.03)\end{array}$ & $\begin{array}{l}-0.77 \\
(0.52)\end{array}$ \\
\hline Percent Black & $\begin{array}{l}11.2 \\
(1.8)\end{array}$ & $\begin{array}{c}4.9 \\
(1.7)\end{array}$ & $\begin{array}{l}5.8 \\
(1.4)\end{array}$ & $\begin{array}{c}5.2 \\
(1.4)\end{array}$ & $\begin{array}{l}2.7 \\
(1.6)\end{array}$ & $\begin{array}{l}1.7 \\
(1.5)\end{array}$ & $\begin{array}{c}-0.3 \\
(1.7)\end{array}$ & $\begin{array}{l}1.0 \\
(2.5)\end{array}$ & $\begin{array}{l}8.0 \\
(1.7)\end{array}$ \\
\hline $\begin{array}{l}\text { Ln (per capita state } \\
\text { income) }\end{array}$ & $\begin{array}{l}-0.75 \\
(0.35)\end{array}$ & $\begin{array}{c}0.00 \\
(0.31)\end{array}$ & $\begin{array}{c}-0.14 \\
(0.28)\end{array}$ & $\begin{array}{c}-0.73 \\
(0.26)\end{array}$ & $\begin{array}{c}-0.78 \\
(0.30)\end{array}$ & $\begin{array}{r}-0.27 \\
(0.28)\end{array}$ & $\begin{array}{l}-0.55 \\
(0.33)\end{array}$ & $\begin{array}{r}-0.50 \\
(0.46)\end{array}$ & $\begin{array}{c}-0.94 \\
(0.28)\end{array}$ \\
\hline $\begin{array}{l}\text { Per capita malt } \\
\text { liquor purchases }\end{array}$ & $\begin{array}{c}0.030 \\
(0.009)\end{array}$ & $\begin{array}{c}0.014 \\
(0.008)\end{array}$ & $\begin{array}{c}0.008 \\
(0.007)\end{array}$ & $\begin{array}{c}0.016 \\
(0.007)\end{array}$ & $\begin{array}{c}0.014 \\
(0.008)\end{array}$ & $\begin{array}{c}0.009 \\
(0.007)\end{array}$ & $\begin{array}{c}0.011 \\
(0.009)\end{array}$ & $\begin{array}{c}0.026 \\
(0.012)\end{array}$ & $\begin{array}{c}0.008 \\
(0.007)\end{array}$ \\
\hline $\begin{array}{l}\text { Effective abortion } \\
\text { rate } \\
(\times 100)\end{array}$ & $\begin{array}{c}0.023 \\
(0.025)\end{array}$ & $\begin{array}{c}0.016 \\
(0.021)\end{array}$ & $\begin{array}{c}0.038 \\
(0.016)\end{array}$ & $\begin{array}{c}0.003 \\
(0.018)\end{array}$ & $\begin{array}{c}-0.021 \\
(0.020)\end{array}$ & $\begin{array}{c}0.012 \\
(0.017)\end{array}$ & $\begin{array}{c}-0.023 \\
(0.022)\end{array}$ & $\begin{array}{c}0.021 \\
(0.030)\end{array}$ & $\begin{array}{r}-0.018 \\
(0.020)\end{array}$ \\
\hline Observations & 304 & 307 & 319 & 315 & 316 & 320 & 316 & 196 & 300 \\
\hline Adj. $R^{2}$ & 0.560 & 0.718 & 0.777 & 0.734 & 0.737 & 0.756 & 0.698 & 0.807 & 0.806 \\
\hline $\begin{array}{l}\text { Coefficient on } \\
\text { drug-share when } \\
\text { other covariates are } \\
\text { excluded }\end{array}$ & $\begin{array}{r}-0.239 \\
(0.129)\end{array}$ & $\begin{array}{c}0.052 \\
(0.125)\end{array}$ & $\begin{array}{r}-0.352 \\
(0.110)\end{array}$ & $\begin{array}{r}-0.280 \\
(0.108)\end{array}$ & $\begin{array}{r}-0.236 \\
(0.120)\end{array}$ & $\begin{array}{r}-0.558 \\
(0.111)\end{array}$ & $\begin{array}{r}-0.430 \\
(0.129)\end{array}$ & $\begin{array}{r}-0.876 \\
(0.192)\end{array}$ & $\begin{array}{r}-0.604 \\
(0.112)\end{array}$ \\
\hline $\begin{array}{l}\text { Coefficient on } \\
\text { drug-share when } \\
\text { median time served } \\
\text { is the dependent } \\
\text { variable }\end{array}$ & $\begin{array}{c}-75.9 \\
(39.2)\end{array}$ & $\begin{array}{l}148.1 \\
(40.0)\end{array}$ & $\begin{array}{c}-34.4 \\
(15.84)\end{array}$ & $\begin{array}{r}-31.7 \\
(7.5)\end{array}$ & $\begin{array}{r}-21.7 \\
(3.9)\end{array}$ & $\begin{array}{r}-32.5 \\
(5.9)\end{array}$ & $\begin{array}{r}-28.6 \\
(4.4)\end{array}$ & $\begin{array}{l}-57.0 \\
(25.9)\end{array}$ & $\begin{array}{r}-35.8 \\
(4.1)\end{array}$ \\
\hline
\end{tabular}

Notes: The dependent variable is the median percentage of maximum sentence that is actually served for the named offense type, among state prisoners released in the current year. If new commitments of drug offenders crowd out time served by other offenders, then the coefficients in the top row would be expected to be negative. State and year fixed effects are included in all specifications. The effective abortion rate is the weighted average of past abortion rates in a state, with weights based on the age distribution of the criminal population (see Donohue and Levitt, 2001). Standard errors in parentheses. All regressions are weighted by the number of valid observations on released prisoners by state and year in the NCRP data set. The bottom row of the table reports coefficients on the drug-share of new prison admissions variable when actual time served in months is the dependent variable. 
of the range, the reduction would be only a few percent; at the high end, the reduction in consumption would be more than $20 \%$.

The coefficients on the violent and property crime punishment proxies are mixed, flipping signs across specifications and in no case achieving statistical significance. Using the state-level cocaine price index we construct, higher unemployment rates and a higher fraction Black are associated with lower cocaine prices, and higher incomes are associated with higher prices. All of these results are plausible. With the city-level price index, the signs on the covariates are less predictable, which is perhaps to be expected since the covariates utilized vary only at the state level.

\section{How does incarceration of drug offenders affect violent and property crime?}

The impact that drug enforcement has on drug prices, and by extension drug consumption, captures only one aspect of the overall impact of drug policy. The impact that drug incarceration has on violent and property crime represents an important public policy question.

Increased punishment of drug offenders may affect violent and property crime through a number of channels. First, to the extent that drug and non-drug offenses are substitutes (complements) for one another, the sharp increase in the 'price' of drug-related crime due to increased punishments would lead to an increase (decrease) in non-drug crime. There is some evidence (Thornberry et al., 1994; Levitt and Venkatesh, 2000) that drug and nondrug crimes may be complements to one another, implying that rising drug penalties reduce other types of crime as well. ${ }^{20}$ Second, regardless of the first point, those imprisoned for drug offenses also engage in violent and property crime. ${ }^{21}$ Thus, holding constant the number of other inmates, an increase in the number of drug prisoners is likely to lower violent and property crimes through incapacitation effects. Of course, given the limited supply of prison cells, it would seem reasonable that incarcerating more drug offenders would crowd out criminals convicted of other offenses, in which case violent and property crime might rise. Finally, punishing drug offenders may change the incentives for engaging in property-rights-related violence or criminal activities by drug users.

20 The results presented in Table 2, while highly speculative, are consistent with drug selling and violence being complements, whereas drug selling and property crime are substitutes. It has also been argued that largescale incarceration of drug offenders has resulted in a greater number of individuals being part of the drug trade at some point in time (because many potential sellers are incarcerated and thus are temporarily unable to sell drugs). If this is true, and one-time exposure to the drug trade increases long-term non-drug criminal activity, then high rates of drug punishment may lead to increased non-drug crime.

21 Beck and Shipley (1989) analyze 3-year re-arrest rates among state prisoners released in 1983. Roughly half of the released prisoners whose most serious offense was drug-related are re-arrested within 3 years. Of those re-arrested, one-fourth are arrested for a violent crime and half are arrested for property offenses. Conversely, for the group of felons who had been incarcerated for either property or violent offenses, one in six is re-arrested on drug charges within 3 years of release. Note also that this study analyzes data from the mid-1980s, when drug arrests were only half the current level and before the peak of crack-related gang violence. If the study were redone today, the overlap between drug and non-drug offenders would likely be even greater. 
The discussion above suggests that a priori we are uncertain how incarcerating drug offenders will affect violent or property crime rates. To explore this issue more formally, we begin by estimating a model with the following structure:

$$
\ln \left(\text { crime }_{s, t}\right)=\sum_{c} \delta_{c} \ln \left(\text { prisoners }_{s, t-1}\right) \cdot\left(\text { prisoner share }_{c s, t-1}\right)+X_{s t}^{\prime} \Gamma+\lambda_{s}+\theta_{t}+\epsilon_{s t}
$$

where $s$ indexes states, $t$ corresponds to years, and $c$ represents different types of crimes (violent, property, drug, or other). The dependent variable is the per capita crime rate. ${ }^{22}$ The specification presented in Eq. (3) mirrors that used in previous research, e.g., Marvell and Moody (1994), Levitt (1996), except that those papers focus exclusively on aggregate prison populations, and thus implicitly restrict the $\delta$ coefficients to be equal across those sentenced for committing different crimes. In contrast, we allow prisoners convicted of violent crime to have a differential impact on crime than those convicted of drug offenses, property offenses, or other offenses. ${ }^{23}$ Both the number of prisoners and the share of prisoners by each type of crime are based on the stock of prisoners in a given state at a particular point in time. The individual $\delta$ 's measure the impact of adding prisoners for a particular type of offense, holding constant the number of prisoners locked up for other offenses, i.e., ignoring any crowd out effects. The difference between any two $\delta$ coefficients is a measure of the impact of adding prisoners of one type while removing prisoners of another type one-for one, i.e., full crowd out. If the marginal criminal sentenced to prison had an identical impact on crime across the four prisoner categories (drug, violent, property, and other), each of the $\delta$ coefficients would be identical, and equal to the elasticity estimated using aggregate prison populations. ${ }^{24}$ If the coefficient $\delta_{d r u g}$ is smaller in absolute value than the other $\delta$ 's, then this would imply that states in which prison population growth has been more heavily concentrated among drug offenders have experienced smaller declines in crime than did states where prison population growth has been less concentrated among drug offenders. The same covariates used earlier are also included in this specification. In order to minimize endogeneity, the prison variable is once lagged.

Table 3 presents separate results using violent and property crime rates as the dependent variable. In columns (1) and (3), baseline estimates using all states and aggregate prison populations are presented. Columns (2) and (4) also report coefficients

22 Holding constant the expected punishment per crime, if crime rises, then the prison population will also rise roughly in proportion to the increase in crime, perhaps with a lag due to delays in prosecution and sentencing. Using the once-lagged value of the prison population avoids this mechanical, reverse-causality driven relationship.

23 Offenses classified as 'other' are made up primarily of weapons offenses, receiving stolen property, fraud, and public order offenses. The specification used is non-standard, but provides the important benefit of allowing us a straightforward means of comparing the estimates on particular types of prisoners to one another and to the overall estimate for all prisoners.

24 Alternatively, one could simply estimate the elasticity of crime with respect to prisoners of different types and calculate the marginal impact evaluated at the mean. We obtain very similar results when doing so. The prison share variables are calculated by the authors using information from NCRP on the number of prisoners sentenced and released by crime type. 
Table 3

The impact on violent and property crime of imprisoning drug offenders versus those committing other types of crimes

\begin{tabular}{|c|c|c|c|c|c|c|}
\hline \multirow[t]{3}{*}{ Variable } & \multicolumn{3}{|c|}{ Dependent variable: $\log$ per capita violent crime } & \multicolumn{3}{|c|}{ Dependent variable: $\log$ per capita property crime } \\
\hline & (1) & (2) & (3) & (4) & (5) & (6) \\
\hline & All states & $\begin{array}{l}\text { Only states with } \\
\text { valid NCRP data }\end{array}$ & $\begin{array}{l}\text { Only states with } \\
\text { valid NCRP data }\end{array}$ & All states & $\begin{array}{l}\text { Only states with } \\
\text { valid NCRP data }\end{array}$ & $\begin{array}{l}\text { Only states with } \\
\text { valid NCRP data }\end{array}$ \\
\hline Logged per capita prison population & $\begin{array}{c}-0.103 \\
(0.033)\end{array}$ & $\begin{array}{c}-0.097 \\
(0.058)\end{array}$ & - & $\begin{array}{c}-0.248 \\
(0.026)\end{array}$ & $\begin{array}{c}-0.165 \\
(0.111)\end{array}$ & - \\
\hline \multicolumn{7}{|c|}{ Logged per capita prison population interacted with: } \\
\hline Drug share of prisoners & - & - & $\begin{array}{c}-0.067 \\
(0.070)\end{array}$ & - & - & $\begin{array}{c}-0.160 \\
(0.081)\end{array}$ \\
\hline Violent crime share of prisoners & - & - & $\begin{array}{r}-0.098 \\
(0.065)\end{array}$ & - & - & $\begin{array}{r}-0.185 \\
(0.076)\end{array}$ \\
\hline Property crime share of prisoners & - & - & $\begin{array}{l}-0.057 \\
(0.066)\end{array}$ & - & - & $\begin{array}{c}-0.156 \\
(0.076)\end{array}$ \\
\hline Other crime share of prisoners & - & - & $\begin{array}{c}-0.094 \\
(0.067)\end{array}$ & - & - & $\begin{array}{c}-0.183 \\
(0.078)\end{array}$ \\
\hline Observations & 612 & 388 & 388 & 612 & 388 & 388 \\
\hline Other covariates included? & Yes & Yes & Yes & Yes & Yes & Yes \\
\hline
\end{tabular}

Difference in key coefficients (standard error in parentheses):

$\begin{array}{llll}\text { Drug prisoner minus violent crime } & - & - & 0.031\end{array}$

prisoner

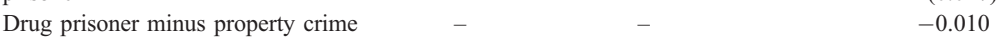

prisoner $\quad(0.012)$

$\begin{array}{llll}\text { Drug prisoner minus other prisoner } & - & - & 0.027\end{array}$

$\begin{array}{cccc}0.0277 & - & - & 0.023\end{array}$

0.025

$(0.016)$

$-0.004$

$(0.018)$

$(0.014)$

Notes: The dependent variable is the logged per capita crime rate for the named crime category. Columns (1) and (4) present results for all states; the remaining columns restrict the sample to those state-year pairs for which valid NCRP data is available. In columns (3) and (6), the logged per capita prison population is interacted with the share of prisoners sentenced for different types of crimes. If the reduction in crime is the same per prisoner across the different offense categories, the coefficients in columns (3) and (6) will all be identical. The bottom three rows of the table provide pair-wise comparisons of the differences between the drug-prisoner coefficient relative to the coefficients for other types of prisoners. In all cases, the prison variables are once-lagged to minimize endogeneity. All regressions include the full set of covariates included elsewhere in the paper, as well as state- and year-fixed effects. Standard errors in parentheses. The regressions in columns (1) and (4) are weighted by state population; the remaining columns are weighted by the number of valid NCRP observations that year. 
for the aggregate prison populations, but limit the sample to the set of states and years for which valid NCRP data are available. Columns (3) and (6) disaggregate by the crime category for which a prisoner is sentenced. The results in columns (1), (2), (4), and (5) are consistent with estimates obtained in previous research utilizing similar specifications. Limiting the sample to the observations with valid NCRP data slightly reduces the magnitude of the estimates and substantially increases the standard errors. ${ }^{25}$ The elasticity of crime with respect to the size of the prison population is roughly -0.10 for violent crime and -0.20 for property crime. Allowing the coefficients to vary by the most serious offense committed by the prisoner yields point estimates on drug offenders that are slightly greater than those for property crime, but smaller than the coefficients associated with violent crime or 'other' offenses. Because the interactions between the prison population and the share of prisoners of each type are highly correlated, the individual point estimates are quite imprecise. The difference between the estimates, however, is much more precisely identified, as shown in the bottom three rows of the table which reports pairwise comparisons of the difference between the coefficients on the drug prisoner variable and the other categories of prisoners. In column (3), for instance, the standard error on the difference between the impact of the drug prisoner and violent prisoner estimates is 0.017 . In spite of these relatively small standard errors, in no case can one reject the null hypothesis that the impact of incarcerating a drug prisoner is identical to the impact of incarcerating criminals convicted of violent, property, or other crimes. ${ }^{26}$ This result is consistent with optimizing behavior on the part of the criminal justice system in allocating scarce prison cells across offenders of different types. Note that these results do not inform the broader question of whether the overall impact of the prohibition of drugs increases or decreases crime, it simply suggests that if the goal is to minimize violent and property crime within the current prohibition regime and the current rate of incarceration, one cannot reject that prison cells are optimally distributed across crime categories.

Between 1980 and 2000, the number of incarcerated drug offenders rose by approximately 375000 people. The total prison population in 2000 (state and federal combined) was roughly 1.3 million. In the absence of crowding out of other prisoners, this 375000 prisoner increase would be associated with an (imprecisely estimated) reduction in crime of $2-5 \%$ (based on the elasticities in Table 3). This estimate, however, is likely to overstate the true impact on crime if crowding out occurred. Indeed, based on the estimates in Table 3, if full crowd out occurred, one cannot reject a prediction that there would be no change in crime.

25 Levitt (1996) finds substantially larger elasticities when using prison overcrowding litigation as an instrument for the size of the prison population. Our estimates in columns (1) and (3) also become more negative when instrumenting in this fashion. Unfortunately, the prison overcrowding litigation instruments have little power to separately identify the impact of prison size by the type of crime committed, i.e., the decline in prisoners in response to the litigation is roughly proportional across crimes. Thus, this instrumenting strategy does not aid in addressing the question of whether incarcerating drug offenders has a differential impact than imprisoning other offenders.

26 The results we report do not account for possible serial correlation. When the results are re-estimated clustering by state (a robust, but potentially inefficient means of dealing with serial correlation), the standard errors increase roughly $25 \%$. Larger standard errors make it more difficult to reject the null of equality for drug prisoners and other types of prisoners. 
The actual degree of crowd out is an empirical question, which we address by estimating specifications of the following form:

$$
\text { Median percent of time served } \text { st }=\beta^{*} \text { DrugShare }_{s t}+X_{s t}^{\prime} \Gamma+\lambda_{s}+\theta_{t}+\varepsilon_{s t}
$$

where $s$ corresponds to states and $t$ to years. The dependent variable in Eq. (4) is the median time served by the cohort released in year $t$ whose most serious conviction was for a particular crime. ${ }^{27}$ Eq. (4) is estimated separately for each crime category. Our measure of the extent of drug incarceration is the percentage of all new prison commitments whose most serious charge is a drug offense for the cohort committed in year $t$. Thus, Eq. (4) relates the composition of the current batch of criminals sent to prison to the sentences actually served by those being released. Assuming that the number of new commitments for drugs does not affect the number of new commitments for other crimes and the prison system is in a steady state, the coefficient $\beta$ has a straightforward interpretation: the degree of crowd-out of the sentences of previously convicted offenders. ${ }^{28}$ A coefficient of -1 implies one-for-one crowd-out; a coefficient of zero corresponds to no crowd-out.

Empirical results from the estimation of Eq. (4) are presented in Table 4 for the FBI index I crimes, as well as fraud and drug offenses. One clear pattern that emerges from the table is that the degree of crowding-out attributable to drug commitments is inversely correlated with the severity of the crime. For the most serious offenses, murder and forcible rape, the point estimates are small and not statistically significant. For the other violent crimes, robbery and aggravated assault, the point estimates are roughly -0.35 . Fraud carries a similar coefficient. For property crimes, the extent of crowd-out is much larger: ranging from -0.53 to -0.93 . Higher rates of new drug commitments reduce the share of the original sentences served by earlier drug offenders to the same extent as they reduce the share served by property crime offenders. Taking a weighted average across crime categories, with weights proportional to the fraction of releases by offense type in our sample, the overall crowd-out estimate is -0.53 in the relatively short time horizon implied by an analysis with year- and state-fixed effects included. Thus, on average, for every two new drug prisoners sent to prison, one represents a real increase in the prison population and the other displaces an existing prisoner who is released early. ${ }^{29}$

The last two rows of Table 4 present coefficients on the drug commitments variable from alternative specifications. Excluding the other covariates in the regression has little

27 Because of the structure of the data, there is no way to effectively compute median time served for the cohort of prisoners entering in a given year.

28 If an increase in new commitments for drugs causes fewer new commitments for other crimes (for instance, due to congestion in courts or policing), then our estimates understate the total degree of crowd out. Empirically, we find no evidence that drug commitments crowd out the number of new prison commitments for other offenses. An alternative way of specifying the model is to use new drug commitment rates per capita, perhaps controlling for the rate of new non-drug commitments. We obtain similar results when that alternative specification is employed, but opt for the model presented because of the ease of interpretation of the coefficients.

29 The crowd out effects we identify are not limited only to new drug commitments. Empirically, increases in the number of offenders sent to prison for other crimes also reduces time served by existing prisoners, as would be expected. The magnitude of the crowd-out effect for non-drug commitments in some cases appears to be smaller than for drug commitments. 
Table 4

The effect of certainty and severity of punishment on cocaine prices

\begin{tabular}{|c|c|c|c|c|c|c|}
\hline \multirow[t]{2}{*}{ Variable } & \multicolumn{3}{|c|}{$\begin{array}{l}\text { Dependent variable: Kuziemko and Levitt } \\
\text { state-level index of cocaine prices }\end{array}$} & \multicolumn{3}{|c|}{$\begin{array}{l}\text { Dependent variable: Rhodes and Kling } \\
\text { city-level index of cocaine prices }\end{array}$} \\
\hline & (1) & (2) & (3) & (4) & (5) & (6) \\
\hline \multicolumn{7}{|l|}{ Arrests per capita for : } \\
\hline Drug offense & $\begin{array}{l}4164 \\
(606)\end{array}$ & - & $\begin{array}{l}3996 \\
(641)\end{array}$ & $\begin{array}{l}6779 \\
(1327)\end{array}$ & - & $\begin{array}{l}8126 \\
(1446)\end{array}$ \\
\hline Violent crime & $\begin{array}{l}3013 \\
(2257)\end{array}$ & - & $\begin{array}{l}-2743 \\
(2970)\end{array}$ & $\begin{array}{l}-1090 \\
(5274)\end{array}$ & - & $\begin{array}{l}7015 \\
(4653)\end{array}$ \\
\hline Property crime & $\begin{array}{l}3266 \\
(1972)\end{array}$ & - & $\begin{array}{l}2498 \\
(2022)\end{array}$ & $\begin{array}{l}-5708 \\
(6295)\end{array}$ & - & $\begin{array}{l}-9914 \\
(6826)\end{array}$ \\
\hline \multicolumn{7}{|l|}{ Severity of Punishment: } \\
\hline Prison commitments per drug-offense arrest & - & $\begin{array}{l}-18.7 \\
(44.4)\end{array}$ & $\begin{array}{l}-0.7 \\
(18.5)\end{array}$ & - & $\begin{array}{l}57.2 \\
(51.0)\end{array}$ & $\begin{array}{l}110.5 \\
(67.6)\end{array}$ \\
\hline Prison commitments per violent-crime arrest & - & $\begin{array}{l}12.7 \\
(19.4)\end{array}$ & $\begin{array}{l}6.8 \\
(10.7)\end{array}$ & - & $\begin{array}{l}33.7 \\
(18.8)\end{array}$ & $\begin{array}{l}18.6 \\
(13.2)\end{array}$ \\
\hline Prison commitments per property-crime arrest & - & $\begin{array}{l}-86.1 \\
(123.1)\end{array}$ & $\begin{array}{l}-58.2 \\
(66.7)\end{array}$ & - & $\begin{array}{l}-102.5 \\
(132.5)\end{array}$ & $\begin{array}{l}-169.2 \\
(106.2)\end{array}$ \\
\hline Covariates (all state-level) & - & & & & & \\
\hline Unemployment rate & $\begin{array}{l}-217 \\
(90)\end{array}$ & $\begin{array}{l}-183 \\
(159)\end{array}$ & $\begin{array}{l}-128 \\
(180)\end{array}$ & $\begin{array}{l}560 \\
(367)\end{array}$ & $\begin{array}{l}590 \\
(384)\end{array}$ & $\begin{array}{l}503 \\
(270)\end{array}$ \\
\hline Percent Black & $\begin{array}{l}-1395 \\
(412)\end{array}$ & $\begin{array}{l}-1139 \\
(347)\end{array}$ & $\begin{array}{l}-1370 \\
(275)\end{array}$ & $\begin{array}{l}1285 \\
(1027)\end{array}$ & $\begin{array}{l}1384 \\
(1446)\end{array}$ & $\begin{array}{l}1638 \\
(1137)\end{array}$ \\
\hline Per capita income & $\begin{array}{l}189 \\
(63)\end{array}$ & $\begin{array}{l}33 \\
(76)\end{array}$ & $\begin{array}{l}43 \\
(63)\end{array}$ & $\begin{array}{l}-70 \\
(111)\end{array}$ & $\begin{array}{l}-105 \\
(126)\end{array}$ & $\begin{array}{l}49 \\
(123)\end{array}$ \\
\hline Per capita beer consumption & $\begin{array}{l}-3.65 \\
(1.62)\end{array}$ & $\begin{array}{l}-1.53 \\
(1.04)\end{array}$ & $\begin{array}{l}0.38 \\
(1.52)\end{array}$ & $\begin{array}{l}7.95 \\
(3.78)\end{array}$ & $\begin{array}{l}5.53 \\
(2.75)\end{array}$ & $\begin{array}{l}4.50 \\
(3.11)\end{array}$ \\
\hline Effective abortion rate & $\begin{array}{l}-0.029 \\
(0.035)\end{array}$ & $\begin{array}{l}0.004 \\
(0.033)\end{array}$ & $\begin{array}{l}0.049 \\
(0.028)\end{array}$ & $\begin{array}{l}0.006 \\
(0.082)\end{array}$ & $\begin{array}{l}-0.025 \\
(0.095)\end{array}$ & $\begin{array}{l}-0.039 \\
(0.088)\end{array}$ \\
\hline Observations & 146 & 138 & 138 & 255 & 244 & 244 \\
\hline$R^{2}$ & 0.913 & 0.914 & 0.950 & 0.907 & 0.886 & 0.904 \\
\hline
\end{tabular}

Notes: The dependent variable in columns (1)-(3) is a state-level index of cocaine prices constructed by the authors and described in the text. The dependent variable in columns (4) - (6) is a citylevel index of cocaine prices constructed by Rhodes and Kling (1997). The unit of observation in columns (1) - (3) is a state-year pair; in columns (4)-(6) the unit of observation is a city-year pair. All regressions include year-fixed effects. Columns (1) - (3) include state-fixed effects; columns (4) - (6) include city-fixed effects. Standard errors in columns (4) - (6) have been corrected to account for the fact that the right-hand-side variables of interest vary only at the state-level. All regressions are weighted by the number of valid NCRP observations that year. 
impact on the coefficients. In the bottom row of the table, we use the actual median time served in months as the dependent variable (as opposed to the percentage of the maximum sentence served). Coefficients from this last row are not readily comparable to those of the other specifications because of the different units of analysis. With the exception of rape, all of the other coefficients on the drug-share variable are negative. A 10 percentage point increase in the share of new commitments on drug charges reduces the median time served for murder by 7.6 months. For other crimes, the corresponding reduction is $2-6$ months. Because the more serious crimes have longer sentences, the percentage reduction in time served is smaller for the violent offenses, consistent with the main findings of the table.

Using our baseline estimate that the total prison population rose by one for every two additional drug prisoners, the best guess as to the impact of the increase in drug imprisonment on violent and property crime is likely to fall in the range of a reduction of $1-3 \%{ }^{30}$ Note that, relative to the remarkable declines in crime experienced in the 1990s (crime fell 50\% in most categories), the estimated contribution of drug imprisonment is minor. Nonetheless, a 3\% reduction in crime equates to about 500 homicides, 12000 robberies and 60000 burglaries annually.

The other coefficients in Table 4 are also of potential interest. When unemployment rates are high, the fraction of the sentence that is served falls slightly: a one percentage point increase in the unemployment rate lowers median time served by about $1 \%$ for most crime categories. Higher state income, however, is associated with serving a shorter fraction of the sentence. Increases in the share of the state population that is black and per capita malt liquor sales correlate with a higher fraction of the sentence being served.

\section{Conclusion}

Despite its public policy importance, there have been few previous attempts to analyze empirically the impact that the unprecedented increase in drug-related imprisonment has had on crime rates or drug markets. Our results suggest that the large increase in drug offender imprisonment increased cocaine prices $5-15 \%$. Given the broad range of existing estimates of the price elasticity of demand for cocaine, the impact of that price change on cocaine consumption could range anywhere from just a few percent to over $20 \%$. On the margin, locking up drug-offenders has roughly the same impact on violent and property crime as incarcerating other types of criminals. There does, however, appear to be a substantial amount of crowding out. Incarcerating more drug offenders leads to the early release of other prisoners. The degree of crowd out varies inversely with the severity of the offense, but the overall level of crowding out is about $50 \%$. Overall, we estimate that the increase in drug incarceration between 1980 and 2000 is associated with a small reduction in violent and property crime of perhaps $1-3 \%$.

The question of foremost public policy interest related to our work is whether or not the investment in drug-offender incarceration has been cost effective. A serious cost-benefit

\footnotetext{
30 This estimate is based on the calculations using the elasticities from Table 3, and dividing them in half to reflect that only half of the increase in drug incarceration represents true increases in the overall prison population due to crowding out.
} 
analysis is beyond the scope of this paper, but a few points are worth making. First, for typical values of the costs of crime, even the most generous estimates of the crime reduction attributable to prison (Levitt, 1996) suggest that current levels of incarceration are excessive. Thus, it is not easy to justify drug imprisonment based on associated declines in violent and property crime alone. The cost-benefit analysis for drug offenders might be more favorable if the externality associated with drug consumption is large. Assuming our estimates are correct, the increase in drug punishment may reduce cocaine consumption by $15 \%$. Given existing estimates of cocaine consumption of 300 metric tons per year, the implied reduction in consumption is 45 metric tons. So for the consumption externality alone to justify the drug incarceration expenditure of $\$ 12$ billion annually (ignoring any benefit associated with reductions in other crimes, as well as foregone utility of the drug users), the externality per pure gram of cocaine would need to be about $\$ 270$, or roughly two and one-half times the street price. Although we are unaware of any reliable estimates of the magnitude of the externalities, this figure would appear to be very high. Harwood et al. (1998) estimate that all illegal drug usage in 1992 was associated with costs of roughly $\$ 30$ billion ( $\$ 12.1$ billion in health care costs and $\$ 17.5$ billion in lost productivity). ${ }^{31}$ Those costs includes not only externalities, but also internalized costs borne by users. Even so, the total costs of drug use they report (both internalized and externalities) add up to only about $\$ 50$ per pure gram of cocaine-well below the $\$ 270$ value noted above.

Furthermore, even if one could conclude that the recent increase in drug punishment were cost effective, it might nonetheless be the case that alternative public policy approaches such as legalization accompanied by large taxes (e.g., Becker et al., 2001), or a greater emphasis on treatment would not have accomplished the same objective more cheaply.

\section{Acknowledgements}

We would like to thank Mark Duggan, Michael Greenstone, Austan Goolsbee, Michael Grossman, Joel Horowitz, Lawrence Katz, Jens Ludwig, Charles Manski, Jeff Miron, two anonymous referees, and the editor, Roger Gordon, for helpful discussions on the topic. The National Science Foundation and Sloan Foundation provided financial support. Jeff Miron generously provided some of the data used in the paper.

\section{Data Appendix}

\section{A.1. Data}

The National Corrections Reporting Program (NCRP) provides the majority of the data for the analysis in this paper. For each year between 1983 and 1996, the NCRP supplies

\footnotetext{
31 The original estimates of Harwood et al. (1998) have been adjusted to year 2000 dollars using the consumer price index.
} 
two separate data sets: admission data, covering those inmates who were admitted to prison that year, and release data, covering those who were released from prison that year. There is no way to reliably link individual prisoners across years. The NCRP relies on official state prison records of the 30-35 states that participate each year. The states participating vary year to year, though about 25 appear in at least 10 of the 14 years the study covers.

The NCRP admission data provides demographic information on each admitted prisoner, as well as information on the offense for which the inmate was convicted and the length of his sentence. The NCRP release data provides all of the information that the admissions data does, in addition to information on the length of time served by the defendant.

The NCRP data were supplemented by a range of state-level covariates used in Donohue and Levitt (2001). All of these variables are from easily available government sources, except per capita malt beverage consumption, which is from the annual publication The Brewers Almanac. All of these covariates are readily available from the authors.

\section{A.2. Constructing the variables}

Our analysis uses variation at the state-year level while the NCRP provides data at the individual-inmate level. For each state-year, the NCRP data was used to generate the medians (and in some cases means) of: (1) sentence length; (2) time served in prison; (3) percentage of sentence actually served using only those inmates convicted of drug offenses. These three calculations were repeated for those inmates convicted of murder, rape, armed robbery, aggravated assault, burglary, auto theft, larceny, fraud, and driving while under the influence of alcohol. An inmate was excluded from the calculation of the summary statistics if he was admitted to prison for a parole violation (instead of directly from a court conviction), or if he/she had missing values for any of the variables required in the calculation. Additionally, the NCRP data was used to calculate the drug share of all new admissions for each state-year, as well as the share of new admissions attributable to each of the other offenses listed above.

Several decisions made in constructing the variables warrant further discussion. First, the percent-of-sentence-served variable was calculated by taking the mean (median) of the individual percent-of-time-served values, instead of dividing the mean (median) timeserved in prison by the mean (median) sentence length. Second, some of the values for the sentence-length variable were changed in order to generate meaningful summary statistics. Those given life sentences were assigned a 50 year sentence for the purpose of calculating mean and median sentences (although this assumption only affects calculation of the means, which are used sparingly in our analysis). In addition, some values for the sentence-length variable were improbably large (such as 1200 months for a burglary conviction). Such values were also changed to 50 years. Third, the time-served variable records only the time served after the inmate was sentenced, and does not include the time he may have served before trial, which is credited toward his sentence. Though the NCRP does in fact provide information on the amount of time served before trial, that information is missing for many observations in the data so we do not use it. 


\section{A.3. Sampling rules}

The NCRP data quality varies from state to state and from year to year. State $i$ in year $t$ was included in the analysis only if it met a number of criteria. First, state $i$ must have had at least 100 new (i.e., not parole violations) admissions in year $t$. Second, state $i$ must have at least 100 new admissions in 10 of the 14 years the NCRP data covers. Third, state $i$ must have a mean (median) value for the percent-of-time-served variable that is less than one in year $t$. Fifth, Hawaii and Missouri were excluded from the analysis due to very poor data quality. Finally, four state-years were eliminated because their drug-share-of-total-admissions variables were vastly incongruent with the values of the same variable in surrounding years.

\section{References}

Alter, J., 2001. A Well-timed 'Traffic' Signal, Newsweek, January 15, p. 29.

Basov, S., Jacobson, M., Miron, J., 2001. Prohibition and the Market for Illegal Drugs: An Overview of Recent History. World Economics 2 (4), 133-158.

Beck, A., B. Shipley, 1989. Recidivism of Prisoners Released in 1983. Bureau of Justice Statistics Special Report, Washington, DC.

Becker, G., Grossman, M., Murphy, K., 1992. Rational Addiction and the Effect of Price on Consumption. In: Lowenstein, G., Elster, J. (Eds.), Choice Over Time. Russell Sage, New York.

Becker, G., Grossman, M., Murphy, K., 2001. The Simple Economics of the War on Drugs, Mimeo, University of Chicago Department of Economics.

Benson, B., Rasmussen, D., 1991. Relationship between Illicit Drug Enforcement Policy and Property Crimes. Contemporary Policy Issues 9 (4), 106-115.

Benson, B., Rasmussen, D., 1994. In: The Economic Anatomy of a Drug War. Rowman and Littlefield, Lanham, MD.

Boaz, D. (editor), 1990. The Crisis in Drug Prohibition. Cato Institute, Washington, DC.

Bureau of Justice Statistics, 1995. In: Flanagan, T., McGarrell, E., Editors. The Sourcebook of Criminal Justice Statistics. US Government Printing Office, Washington, DC.

Chaloupka, F.J., Grossman, M., Tauras, J.A., 1999. The demand for cocaine and marijuana by youth. In: Chaloupka, F., Grossman, M., Bickel, W.K., Saffer, H. (Eds.), The Economic Analysis of Substance Use and Abuse. The University of Chicago Press, Chicago, IL, pp. 133-155.

DeSimone, J., 1998. Is marijuana a gateway drug? Eastern Economic Journal 24 (2), 149-164.

Donohue, J., Levitt, S., 2001. Legalized abortion and crime, Quarterly Journal of Economics (in press).

Donziger, S., 1996. The Real War on Crime: The Report on the National Criminal Justice Commission. Harper Collins, New York.

Drug Enforcement Agency, 1996. The South American Cocaine Trade: An "Industry" in Transition. U.S. Department of Justice, Washington, D.C.

Duke, S., Gross, A., 1993. America’s Longest War. Putnam, New York.

Everingham, S.S., Rydell, C.P., Caulkins, J., 1995. Cocaine consumption in the United States: estimating past trends and future scenarios. Socio-Economic Planning Science 29 (4), 305-314.

Farrelly, M., Bray, J., Zarkin, G., Wendling, B., 2000. The joint demand for cigarettes and marijuana: evidence from the National Household Surveys on Drug Abuse. Journal of Health Economics 20, 51-68.

Fisher, F., Nagin, D., 1978. On the feasibility of identifying the crime function in a simultaneous equations model of crime and sanctions. In: Blumstein, A., Nagin, D., Cohen, J. (Eds.), Deterrence and Incapacitation: Estimating the Effects of Criminal Sanctions on Crime Rates. National Academy of Sciences, Washington, DC.

Grossman, M., Chaloupka, F., 1998. The demand for cocaine by young adults: a rational addiction approach. Journal of Health Economics 17, 427-474. 
Harwood, H., Fountain, D., Livermore, G., 1998. The economic costs of alcohol and drug abuse in the United States, 1992. NIH Pub. No. 98-4327. National Institutes of Health, Rockville, MD.

Levitt, S., 1996. The effect of prison population size on crime rates: evidence from prison overcrowding litigation. Quarterly Journal of Economics 111, 319-352.

Levitt, S., 1998. Why do increased arrest rates appear to reduce crime: deterrence, incapacitation, or measurement error? Economic Inquiry 36, 353-372.

Levitt, S., Venkatesh, S., 2000. An economic analysis of a drug-selling gang's finances. Quarterly Journal of Economics 115, 755-789.

Liu, J.-L., 1999. The price elasticity of opium in Taiwan, 1914-1942. Journal of Health Economics 18, $795-810$.

MacCoun, R.J., Reuter, P., 2001. Drug War Heresies. Cambridge University Press, Cambridge.

Marvell, T., Moody, C., 1994. Prison population growth and crime reduction. Journal of Quantitative Criminology $10,109-140$.

Miron, J., 1999. Violence and the US prohibitions of drug and alcohol. American Law and Economics Review 1 $(1-2), 78-114$.

Miron, J., 2000, Prohibitions and the Prices of Prohibited Goods: Evidence from the Markets for Heroin and Cocaine, unpublished manuscript, Boston University.

Miron, J., Zweibel, J., 1995. The economic case against drug prohibition. Journal of Economic Perspectives 9 , 175-192.

Moore, M., 1990. Supply Reduction and Drug Law Enforcement. Crime and Justice 13, 109-158.

Nadelman, E., 1997. Drug prohibition in the U.S.: costs, consequences, and alternatives. In: Reinaraman, C., Levine, H. (Eds.), Crack in America University of California Press, Berkeley, CA.

National Research Council, 2001. Informing America’s Policy on Illegal Drugs: What We Don’t Know Keeps Hurting Us, Committee on Data and Research for Policy on Illegal Drugs. Manski, C.F., Pepper, J.V., Petrie, C.V., Editors. National Academy Press, Washington, DC.

Pacula, R., Grossman, M., Chaloupka, F.J., O’Malley, P.M., Johnston, L.D., Farrelly, M.C., 2001. Marijuana and youth. In: Gruber, J. (Ed.), Risky Behavior among Youths: An Economic Analysis. University of Chicago Press, Chicago, IL.

Perez-Pena, R., 2001. Pataki Presents Plan to Ease Laws on Drugs. New York Times, January 18.

Reinarman, C., Levine, H., 1997. The crack attack: politics and media in the crack scare. In: Reinaraman, C., Levine, H. (Eds.), Crack in America University of California Press, Berkeley, CA.

Rhodes, W., Kling, R., 1997. Prices of Illicit Drugs: 1981-1997, Memo from Abt Associates to the Office of National Drug Control Policy.

Rhodes, W., Langenbahn, S., Kling, R., Scheiman, P., 1998. What America's Users Spend on Illegal Drugs, 1988-95, ABT Associates report prepared for the Office of National Drug Control Policy, Cambridge, MA.

Saffer, H., Chaloupka, F., 1995. The Demand for Illicit Drugs. NBER Working Paper No. 5238.

Selke, W., 1993. Prisons in Crisis. Indiana University Press, Bloomington, IN.

Thornberry, T., Lizotte, A., Krohn, M., Farnworth, M., Jang, S.J., 1994. Delinquent peers, beliefs, and delinquent behavior: a longitudinal test of interactional theory. Criminology 32 (1), 47-83.

Van Ours, J., 1995. The price elasticity of hard drugs: the case of opium in the Dutch East Indies, 1923-1938. Journal of Political Economy 103, 261-279. 